\title{
Development of In vitro Slow Growth Culture for Yam (Dioscorea alata L.)
}

\author{
Villaluz Z. Acedo and Catherine C. Arradaza \\ Tissue Culture Laboratory, PhilRootcrops, Visayas State University, \\ Baybay, Leyte, 6521-A Phillipines
}

\begin{abstract}
Germplasm collections, the lifeblood of breeding programs, are traditionally maintained in the field. Field genebanks are expensive, subject to genetic erosion, and require several quarantine measures for safe movement of genetic materials. These problems are more serious in long-duration, non-flowering and vegetatively propagated crops like yam. This study aimed to develop a tissue culture technique for in vitro conservation of yam germplasm. 'VU-2' and 'Kinampay' varieties were used in establishing the in vitro conservation technique which was then tested to other genotypes. With the tissue culture protocol for yam propagation developed earlier, the plantlets became overgrown after 2-3 months, requiring frequent subculturing and increasing the cost of maintenance and the risk of microbial contamination. Slow growth culture was tested using MS medium added with $0-10 \mathrm{mg} / \mathrm{L}$ abscisic acid (ABA) or 0-7\% mannitol or sorbitol. Expectedly, plantlet growth slowed down. However, ABA at higher levels increased mortality of cultures while sorbitol was less effective than mannitol in retarding growth. Mannitol at $4 \%$ was found to be the best slow growth medium to maintain the plantlets for 13 months, thereby saving at least 4 times the maintenance cost using the normal growth medium. Tissue viability, morphological stability and tuber yield were not affected. Other genotypes (VU-1, VU-3, VU-4, VU-5, PR5, PR7, PR10 and PR11) responded similarly to the slow growth culture condition.
\end{abstract}

Keywords: yam, Dioscorea alata, germplasm, mannitol, sorbitol, ABA, slow growth

Correspondence: V. Z. Acedo. Address: PhilRootcrops, VSU, Baybay, Leyte, 6521-A

Philippines.E-mail: luzacedo@yahoo.com.Tel. No.63-53-5637077.Tel/Fax: 63-53-335-

2616

DOI: $10.32945 /$ atr3415.2012 


\section{INTRODUCTION}

Yam or ubi (Dioscorea alata L.) is a major root crop with great economic potential. Its tubers and products (e.g. ubi powder) have high domestic and export demands estimated to be equivalent to 49,000 metric tons of tubers or about $50 \%$ higher than the country's production of 25,000 metric tons (Bureau of Agricultural Statistics, 1997). Philippine ubi products also have a competitive advantage in the global market. Because of this, the Department of Trade and Industry identified ubi as one of the country's banner export crops. To meet present and future demands, continuing efforts to expand and intensify production are imperative and integral to this, a strong crop improvement program must be pursued.

Germplasm collection is the lifeblood of crop improvement programs. The more diverse the collections, the wider the genetic base for breeding works. The Philippine Root Crops Research and Training Center (PhilRootcrops) has about 600 yam accessions, one of the most diverse in Asia. These collections are maintained in the field requiring large growing area. Aside from being expensive and hard to manage, field genebanks are prone to genetic erosion due to biotic (e.g. diseases, insect pests) and abiotic (e.g. typhoons, drought, flooding) factors (Rodriguez et al., 2003). In addition, several quarantine measures have to be adhered to for safe movement and exchange of genetic materials (Malaurie et al., 1998). These problems are more serious in long-duration, non-flowering and vegetatively propagated crops like yam.

In vitro genebank could overcome the limitations of field genebank. Through appropriate tissue culture techniques, genetic materials are conserved in a small space at reduced cost and free of risks from field factors. In vitro germplasm collections could also be made free of diseases, which is of particular concern with vegetatively propagated crops, being seriously affected by an accumulation of pathogens (Malaurie et al., 1998). If used to complement field genebank, in vitro genebank prevents loss of genetic materials and assures better security of germplasm conservation. In vitro genebank preservation could be done under normal growth conditions but this is only suitable for temporary storage of germplasm collections. At PhilRootcrops, the in vitro culture technique developed for yam propagation would produce overgrown plantlets after 2-3 months incubation (Acedo, 2003). As a consequence, frequent subculturing is needed, increasing the cost of maintenance and the risk of microbial contamination. These limitations can be eliminated by employing the slow 
growth culture which is considered as an active in vitro genebank (Malaurie et al., 1998). Different slow growth conditions have been found for different yam species. For D. alata, the basal D-571 medium added with mannitol: benzylaminopurine:activated charcoal at 1.5:0.1-1.0:2 ratio was found to be the best condition that kept the plantlets for 9 months without subculture (Rodriguez et al., 2003). For D. bulbifera, half strength MS or B5 medium added with $12 \%$ sucrose and $0.5 \mathrm{mg} / \mathrm{l}$ abscissic acid (ABA) kept the plantlets for 15 months without loss of morphogenetic capacity (Okezie, 2003). At CIRAD-ORSTOM, France, 20 yam species are being maintained in slow growth medium with low mineral nutrient and sucrose levels but subculture is done every 6-8 months (Malaurie et al., 1998). The present study developed a different and easy slow growth culture technique that kept the plantlets of different $D$. alata varieties and accessions for more than a year without affecting morphological stability and ex vitro performance.

\section{MATERIALS AND METHODS}

\section{In vitro Stockplants}

Recommended yam varieties (VU-1, VU-2, VU-3, VU-4, VU-5 and 'Kinampay') and selected genotypes (PR5, PR7, PR10 and PR11) were used. Donor plants were raised in the greenhouse and served as explant source for in vitro stockplant establishment following the protocol of Acedo (2003).

\section{Slow Growth Experiments}

Slow growth experiments were conducted using single nodal segments from in vitro stockplants, with 'Kinampay' and 'VU-2' as test varieties. The Murashige and Skoog (1962) or MS nutrients were used as the basal medium components. Three experiments were conducted wherein the basal medium was supplemented with ABA, mannitol or sorbitol at different concentrations. For sorbitol and mannitol experiments, the treatments were based on the results of previous study that tested concentrations lower than 5\%. Sucrose was added at 3\% and Sigma agar at $0.7 \%$. The $\mathrm{pH}$ of the medium was adjusted to 5.8 before dispensing at $10 \mathrm{ml}$ per test tube. The medium was sterilized at 15 psi for 15 minutes. Each test tube was inoculated with one explant. The cultures were maintained 
in culture shelves illuminated by white fluorescent tubes under a room temperature of $25 \pm 2{ }^{\circ} \mathrm{C}$. Root and shoot development was monitored. From these experiments, the most promising slow growth medium was identified and tested to other varieties/genotypes. The different experiments were conducted using CRD with three replicates per treatment and 15 samples per replicate.

\section{Viability Testing and ex vitro Evaluation}

Plantlets stored for 13 months were transferred to normal growth medium (Acedo, 2003) to determine if they are still capable to resume normal growth. The regenerated plantlets were micropropagated and potted out for ex vitro evaluation for morphological variations and tuber yield. As potting medium, $30 \times 30 \times 40 \mathrm{~cm}$ black polyethylene bags containing garden soil and rice hull at 3:1 ratio were used. Harvesting was done 4 months later.

\section{RESULTS AND DISCUSSION}

\section{ABA Effects on Plantlet Development}

ABA delayed root and shoot initiation in both 'Kinampay' and 'VU2' nodal cultures (Fig 1A-B and Fig 2A-B). ABA at $1 \mathrm{mg} / \mathrm{L}$ appeared to be sufficient in retarding root and shoot formation in 'Kinampay'. At higher concentration of $5-10 \mathrm{mg} / \mathrm{L}$, less than $60 \%$ of the cultures formed roots (Fig 1A) and shoots (Fig 2A). The tissues that did not show signs of growth turned brown with incubation. In 'VU2', higher percentage root and shoot initiation was obtained even at higher ABA levels. Root formation was sufficiently retarded at $1 \mathrm{mg} / \mathrm{L} \mathrm{ABA} \mathrm{(Fig.} \mathrm{1B)} \mathrm{while} \mathrm{shoot} \mathrm{formation} \mathrm{was}$ additionally delayed as ABA concentration increased (Fig. 2B).

The number of roots did not differ much across treatments after 1 month (Figs. 1C-D). However, ABA-treated cultures had shorter roots than untreated ones in both varieties (Figs. 1E-F). After 3 months, when the untreated control became overgrown, both root number and length decreased with ABA treatment. Higher ABA levels were more inhibitory to root production while all $A B A$ levels comparably inhibited root elongation. After 6 months of incubation, root production remained suppressed in cultures treated with 5-10 mg/L ABA for 'Kinampay 'and $10 \mathrm{mg} / \mathrm{L} \mathrm{ABA} \mathrm{in}$ 'VU2'. All ABA treatments resulted to shorter roots than that obtained for 

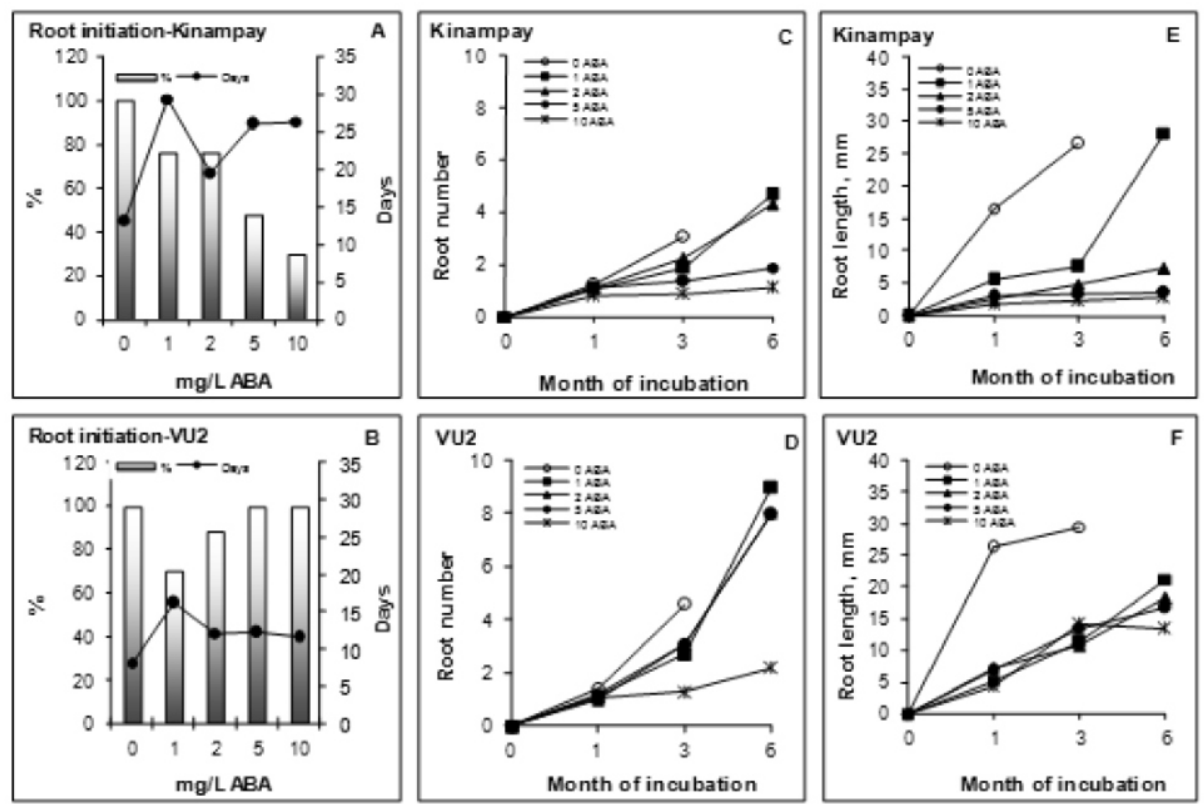

Figure 1. Root development in nodal cultures of 'Kinampay' and 'VU2' yam treated with $0-10 \mathrm{mg} / \mathrm{LABA}$.

the control after 3 months incubation, except for 'Kinampay' treated with 1 $\mathrm{mg} / \mathrm{L} \mathrm{ABA}$.

In terms of shoot development, production of the first open leaf was delayed with increasing $A B A$ concentration up to $5 \mathrm{mg} / \mathrm{L}$ in both 'Kinampay' (Fig. 2C) and 'VU2' (Fig. 2D) cultures. At $10 \mathrm{mg} / \mathrm{L} \mathrm{ABA}$, less than $40 \%$ of the live cultures produced an open leaf. This happened earlier in Kinampay than in VU2 as compared to when $5 \mathrm{mg} / \mathrm{LABA}$ was used. ABA's inhibitory effect on shoot growth, which generally increased with increasing concentration, was also evident in terms of the number of leaves (open and non-open) produced (Figs. 3A-B) and length of shoots (Figs. 3CD). After 6 months incubation, all ABA-treated cultures had still fewer number of leaves than that obtained for the control after 3 months incubation, except for that treated with $1 \mathrm{mg} / \mathrm{L} \mathrm{ABA}$. Shorter shoots were also obtained. $10 \mathrm{mg} / \mathrm{L} \mathrm{ABA}$ caused the greatest inhibition of shoot elongation. It also appeared to induce shoot branching in 'VU2' cultures but not in 'Kinampay'. Figure 4 shows the growth appearance of plantlets with or without ABA treatment.

The results demonstrate the potential of ABA to retard growth of 'Kinampay' and 'VU2' nodal tissues during in vitro storage. After 6 months 

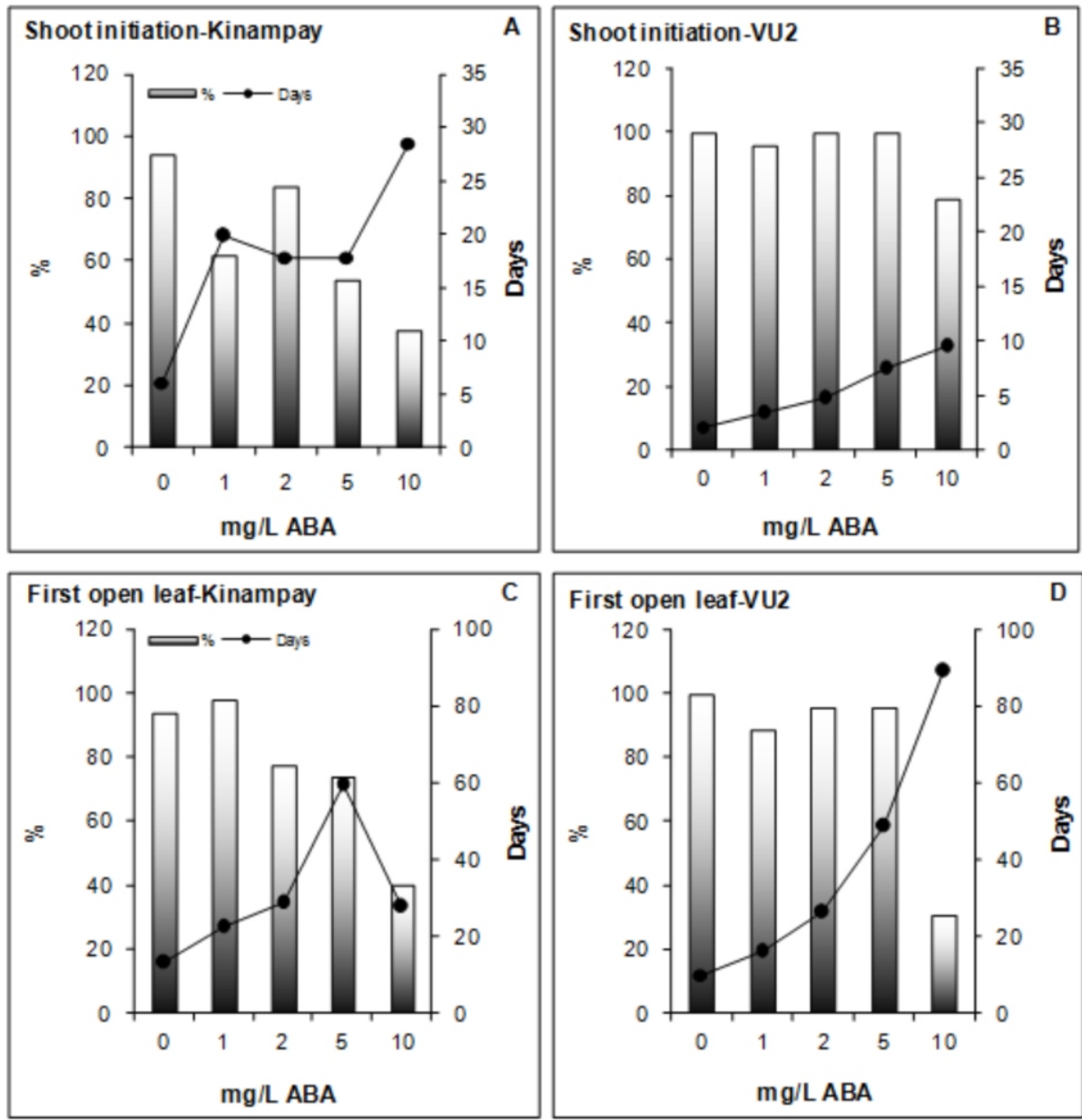

Figure 2. Shoot initiation and production of first open leaf in nodal cultures of 'Kinampay' and 'VU2' yam treated with $0-10 \mathrm{mg} / \mathrm{L}$ ABA.

incubation, nodal cultures in 1-2 mg/L ABA were not yet overgrown and hence can still be maintained in the same condition. ABA at $5-10 \mathrm{mg} / \mathrm{L}$ caused the greatest growth inhibition but increased tissue mortality.

\section{Sorbitol Effects on Plantlet Development}

Increasing sorbitol concentration resulted to decreasing percentage root and shoot initiation in 'Kinampay' (Fig. 5A and Fig. 6A) but not in 'VU2' (Fig. 5B and Fig. 6B). Root and shoot initiation was most effectively delayed 

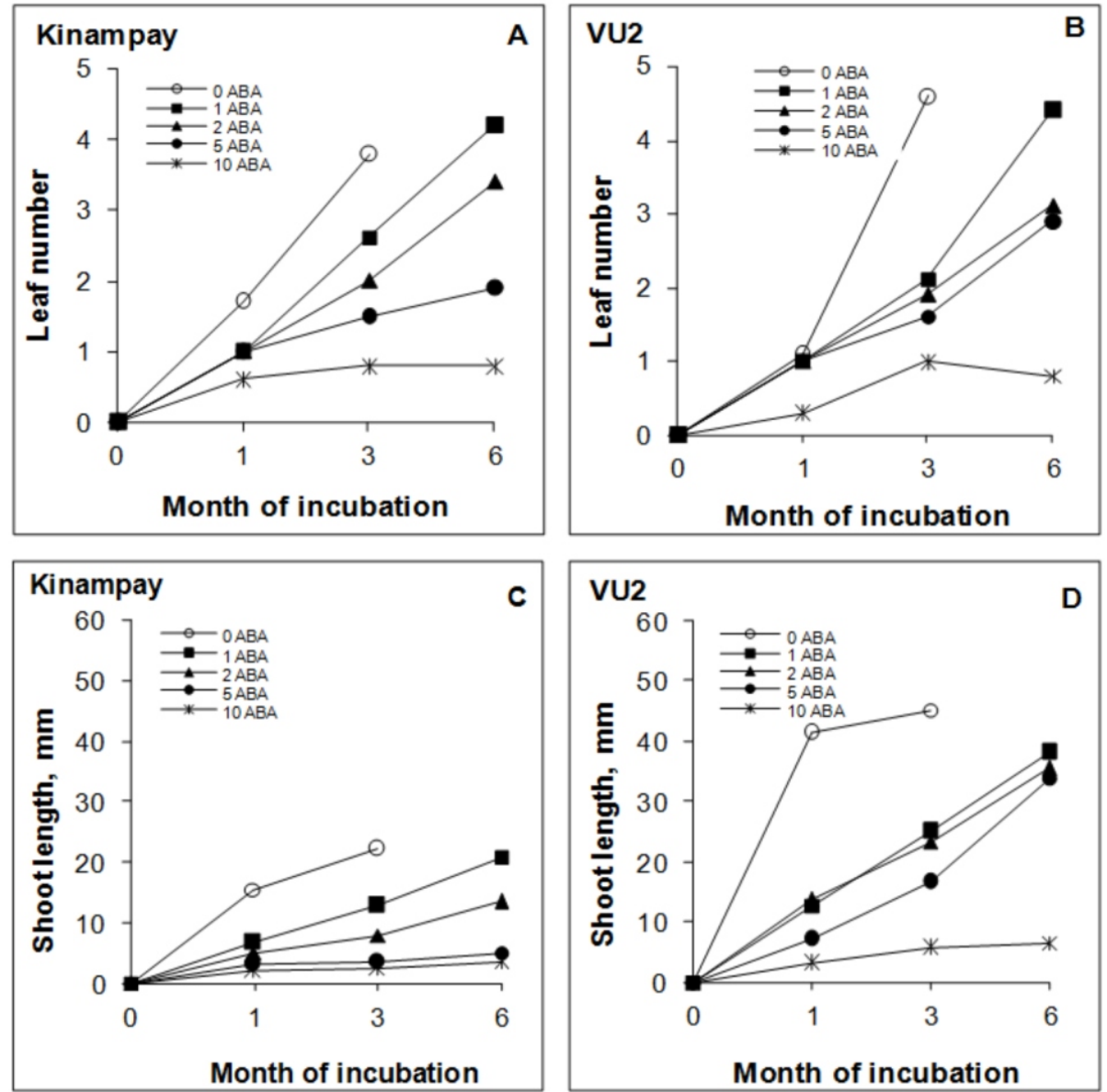

Figure 3. Leaf number and shoot length of nodal cultures of 'Kinampay' and ' V U 2 ' y a m treated with $0-10 \mathrm{mg} / \mathrm{LABA}$.

at $6 \%$ sorbitol in 'Kinampay' with tissue survival of about $80 \%$ and at $7 \%$ sorbitol in 'VU2' with $100 \%$ survival rate.

The number of roots did not widely differ with treatments in both varieties (Figs. 5C-D). In contrast, root length markedly decreased with sorbitol treatment (Figs. 5E-F). In 'Kinampay', root length was distinctly shorter in 5-6\% sorbitol-treated cultures than that of the other treatments. The $7 \%$ sorbitol treatment was discarded due to increasing tissue mortality as the incubation period progressed. In 'VU2', inhibition of root elongation was noted in all sorbitol-treated cultures after 1-3 months 
Kinampay
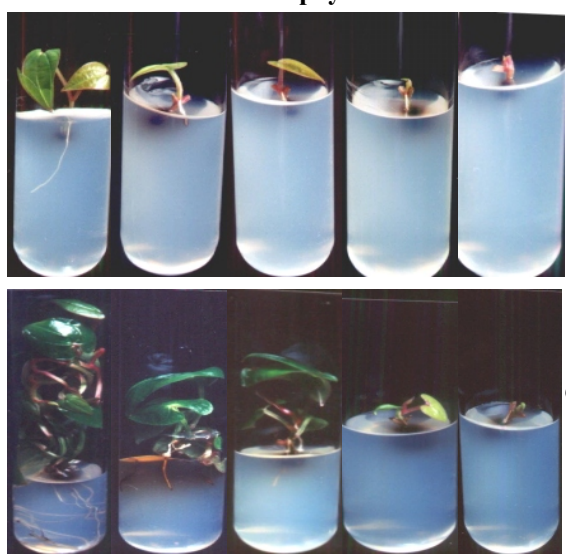

a b d

e

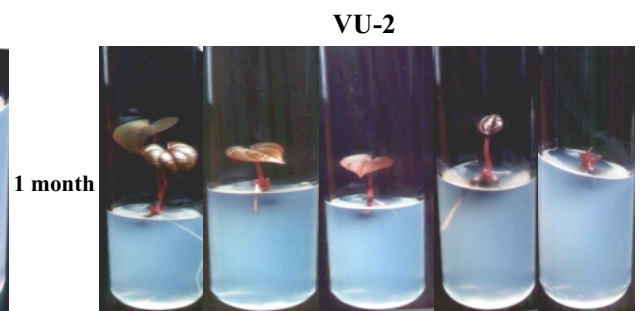

Figure 4. Growth of 'Kinampay' and 'VU2' yam nodal cultures after 1 and 6 months of incubation in ABA-added medium: (a) control; (b) $1 \mathrm{mg} / \mathrm{L}$; (c) $2 \mathrm{mg} / \mathrm{L}$; (d) 5 $\mathrm{mg} / \mathrm{L}$; and (e) $10 \mathrm{mg} / \mathrm{L}$.
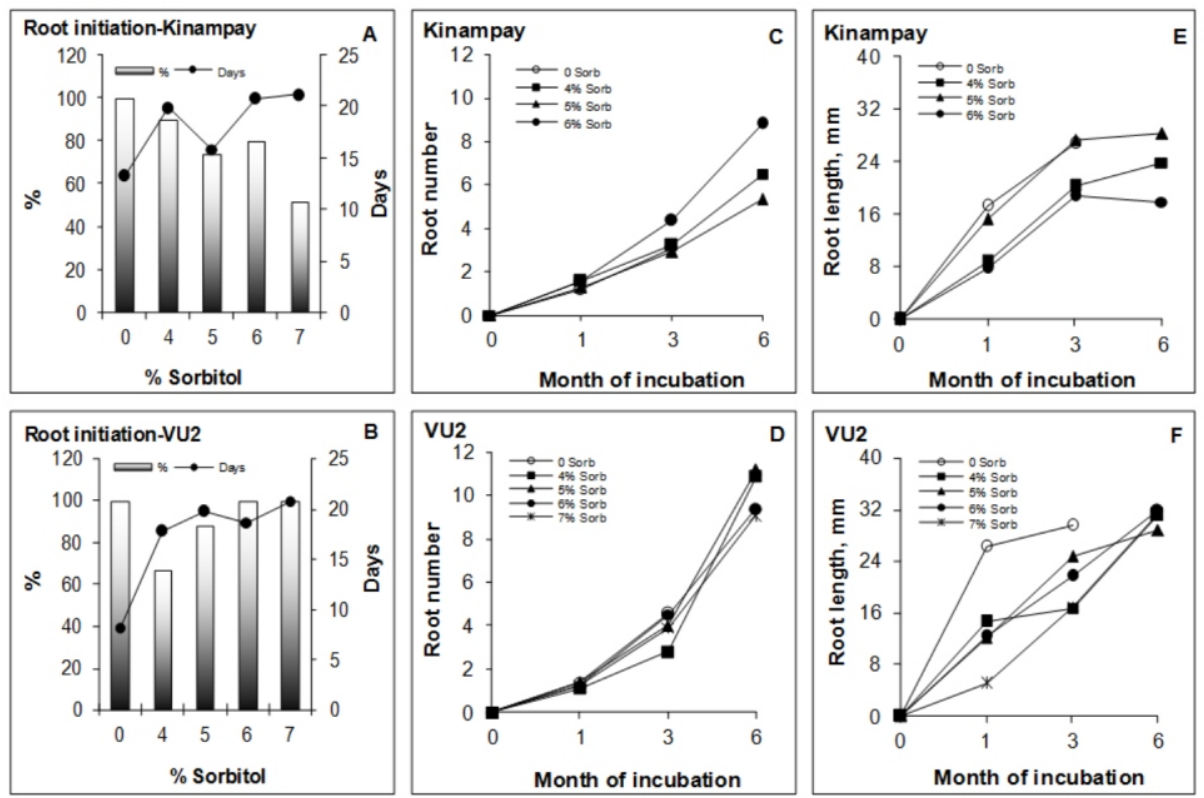

Figure 5. Root development in nodal cultures of 'Kinampay' and 'VU2' yam treated with 0$7 \%$ sorbitol. 
incubation, with the $7 \%$ concentration consistently being the most effective. After 6 months incubation, root length in all sorbitol-treated cultures was comparable to that obtained for the control after 3 months incubation.

Sorbitol also delayed the production of the first open leaf in both varieties (Figs. 6C-D). However at 7\%, the number of live cultures producing leaves decreased to less than $60 \%$. In terms of number of leaves, treatment effects did not greatly differ (Figs. 7A-B). Shoot length decreased with sorbitol treatment, particularly in 'VU2' with the 7\%
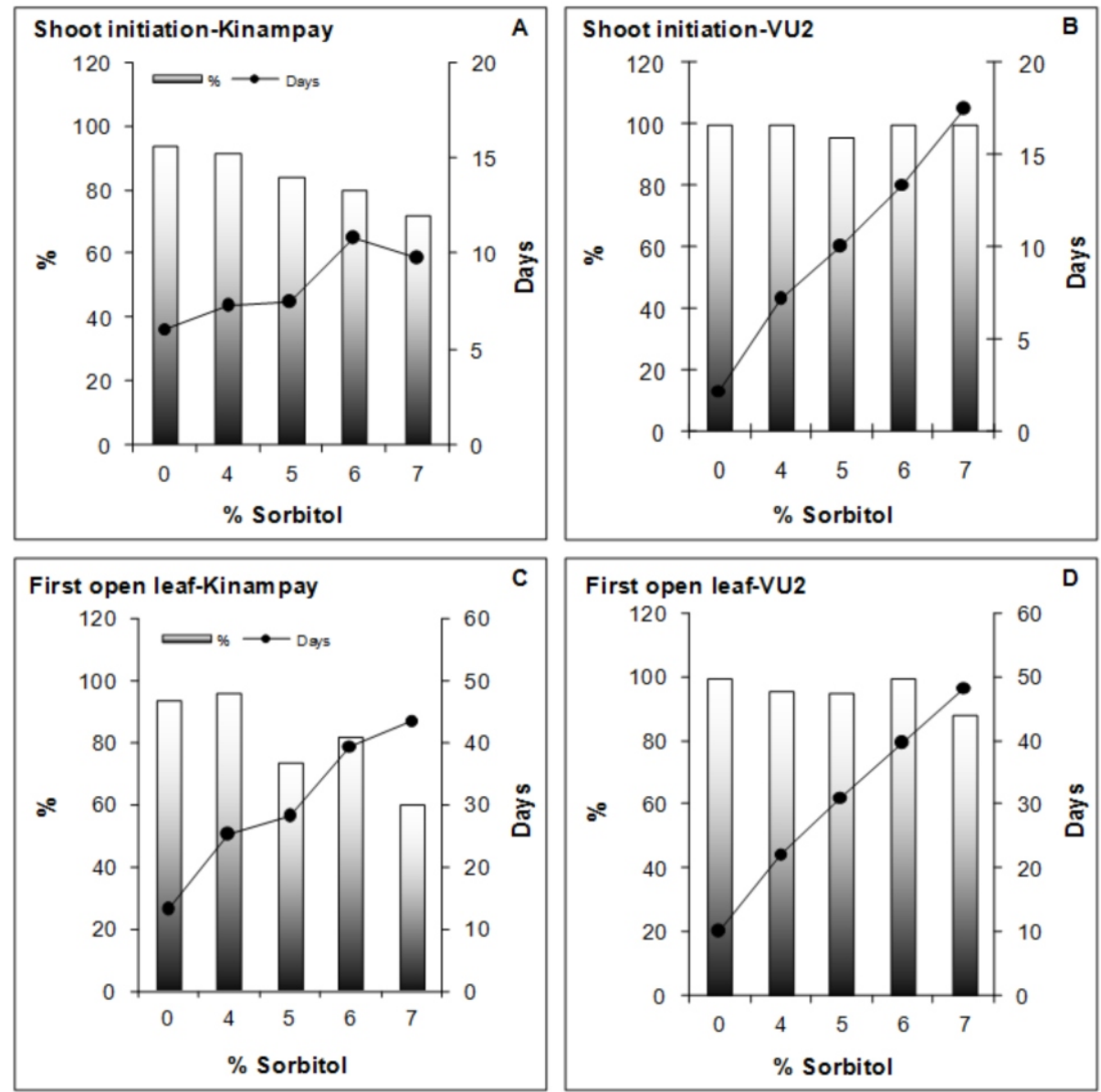

Figure 6. Shoot initiation and production of first open leaf in nodal cultures of 'Kinampay' and 'VU2' yam treated with 0-7\% sorbitol. 
sorbitol causing the greatest inhibition (Fig. 7D). In 'Kinampay', only the $6 \%$ sorbitol treatment consistently retarded shoot elongation (Fig. 7C). It also promoted shoot branching (Fig. 7E). Shoot branching in 'VU2' similarly increased after 3-6 months incubation when 5-7\% sorbitol was used (Fig. 7F). Figure 8 shows the growth appearance of plantlets with or without sorbitol treatment.

\section{Mannitol Effects on Plantlet Development}

High percentage root (Figs. 9A-B) and shoot (Figs. $10 \mathrm{~A}-\mathrm{B}$ ) initation of $80 \%$ or higher was obtained regardless of mannitol level, except for the $6 \%$ mannitol-treated 'Kinampay' cultures in which only $60 \%$ formed roots. In terms of the period of time to root and shoot initiation, mannitol had a marked delaying effect. Mannitol at 7\% caused the greatest delay in root initiation by about 2-fold in 'Kinampay' and 4-fold in 'VU2' relative to that of untreated ones. Mannitol at 4-6\% had comparable delaying effect. On the other hand, the delay in shoot initiation was greatest with $5 \%$ mannitol in 'Kinampay' and 7\% mannitol in 'VU2'.
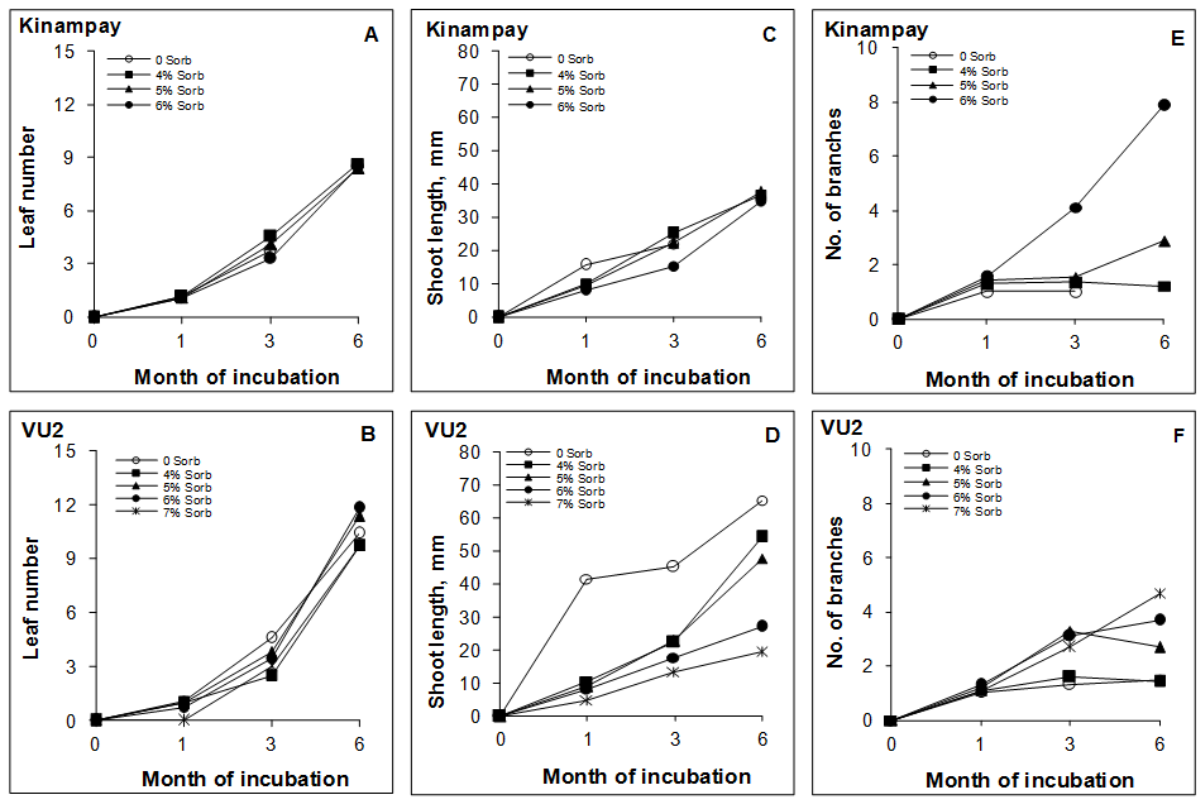

Figure 7. Number of leaves and branches and shoot length of nodal cultures of 'Kinampay' and 'VU2' yam treated with $0-7 \%$ sorbitol. 
Mannitol distinctly inhibited root development, particularly root length (Figs. 9E-F). In 'Kinampay', root length was only about $10 \mathrm{~mm}$ or shorter after 6-9 months in all mannitol-treated cultures whereas the untreated control, $>25 \mathrm{~mm}$ after only 3 months (Table 1, Fig. 9E). Higher mannitol levels of 6-7\% resulted to greater inhibition of root elongation. In 'VU2', root elongation was similarly retarded but not as marked as that in 'Kinampay'. In terms of number of roots, mannitol-treated cultures had much fewer roots than the control only after 3 months (Figs. 9C-D). Among mannitol-treated cultures, root growth inhibition did not vary markedly (Table 1).

The production of first open leaf was increasingly delayed with increasing mannitol level in 'VU2' and at 7\% mannitol; it took more than 6 times the time duration taken by the untreated cultures (Fig. 10D). In 'Kinampay', 5\% mannitol was sufficient to elicit the effect (Fig. 10C). Although there was an additional delay in the production of the first open leaf when $7 \%$ mannitol was used, the number of cultures producing open leaves decreased to less than $80 \%$. Mannitol inhibition of shoot growth was also very evident in terms of shoot length (Figs. 11C-D) but not so in
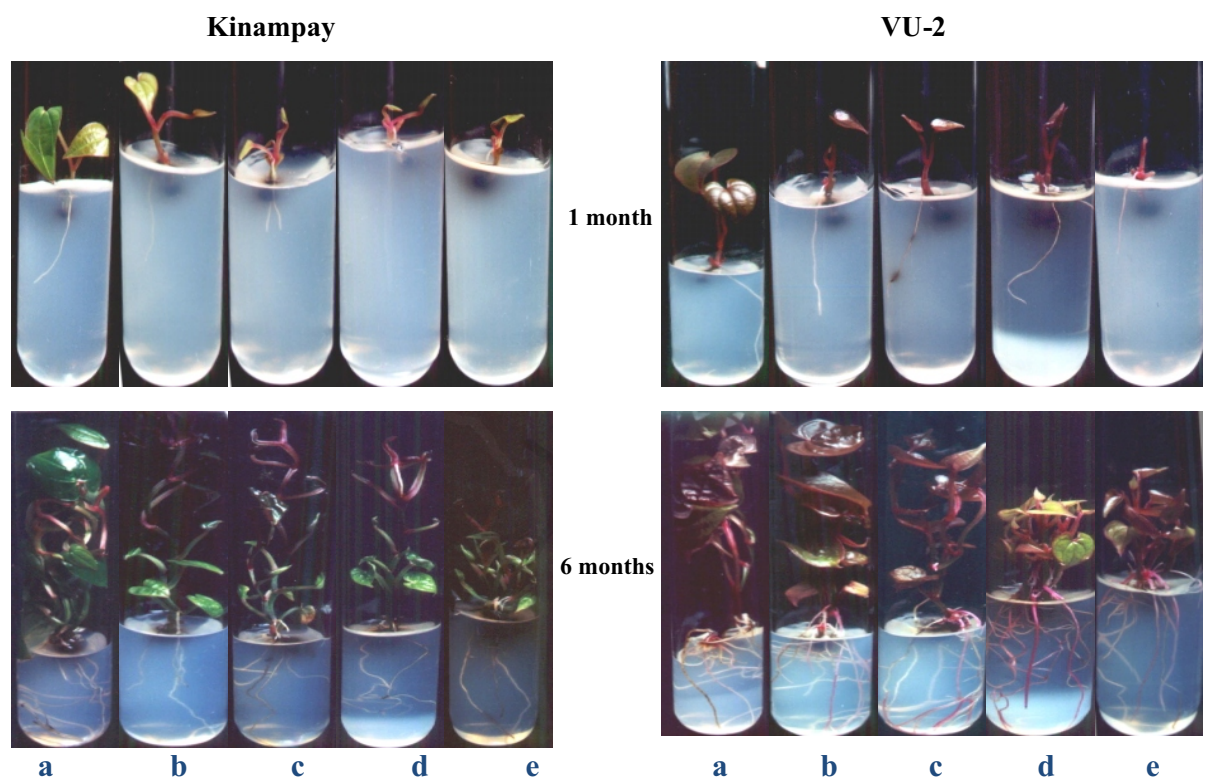

Figure 8. Growth of 'Kinampay' and 'VU2' yam nodal cultures after 1 and 6 months of incubation in sorbitol-added medium: (a) control; (b) 4\%; (c) 5\%; (d) 6\%; and (e) $7 \%$. 

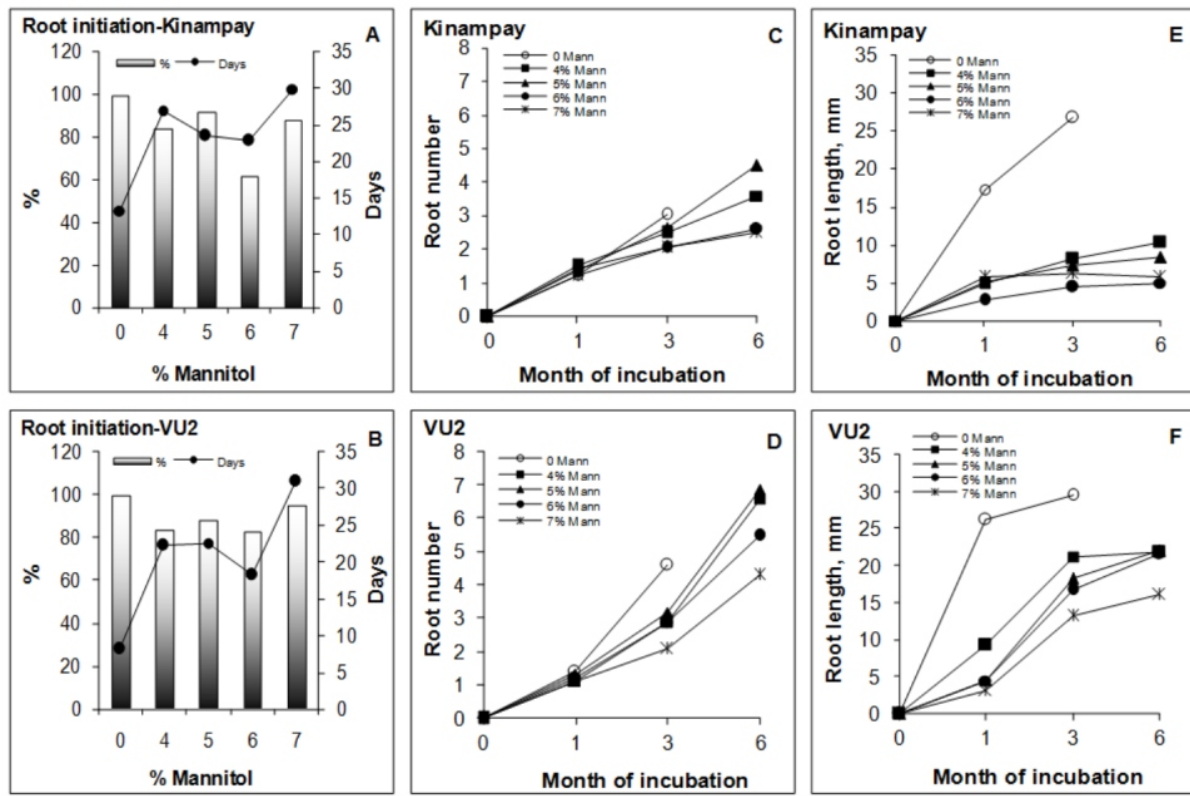

Figure 9. Root development in nodal cultures of 'Kinampay' and 'VU2' yam treated with 0$7 \%$ mannitol.

terms of number of leaves in which only the 6-7\% mannitol caused marked reduction relative to the control in both varieties (Figs. 11A-B). Shoot length was reduced more effectively at $5-7 \%$ than at $4 \%$ mannitol in 'Kinampay' while in 'VU2', 7\% mannitol caused the greatest reduction in shoot length after 9 months (Table 1). Another peculiar response was the occurrence of shoot branching, but it seemed to be variety-specific (Figs. $11 \mathrm{E}-\mathrm{F}$ ). In 'Kinampay', shoot branching increased with increasing mannitol concentration while in 'VU2', the opposite trend was noted. Figure 12 shows the growth appearance of plantlets with or without mannitol treatment.

The results show that mannitol, even at the highest concentration (7\%), did not greatly affect tissue survival, unlike ABA at 5-10 mg/L. Mannitol was also more effective than sorbitol in slowing down growth of plantlets. The cultures were not overgrown yet after 9 months. In fact, some cultures were maintained for more than a year without subculture. 
Table 1. Root and shoot growth of 'Kinampay' and 'VU2' yam cultures after 9 months incubation in mannitol-added medium.

\begin{tabular}{lcccc}
\hline \% Manitol & \multicolumn{2}{c}{ Root Growth } & \multicolumn{2}{c}{ Shoot Growth } \\
\cline { 2 - 5 } & No. of Roots & Root Length $(\mathrm{mm})$ & Shoot length $(\mathrm{mm})$ & No. of Branches \\
\hline Kinampay & & & & - \\
0 (Control $\left.^{*}\right)$ & - & - & - & $4.4 \mathrm{a}$ \\
4 & $3.7 \mathrm{~b}$ & $6.6 \mathrm{~b}$ & $12.8 \mathrm{a}$ & $6.5 \mathrm{a}$ \\
5 & $5.4 \mathrm{a}$ & $10.2 \mathrm{a}$ & $9.8 \mathrm{~b}$ & $6.6 \mathrm{a}$ \\
6 & $3.2 \mathrm{~b}$ & $5.4 \mathrm{~b}$ & $8.3 \mathrm{c}$ & $10 \mathrm{~b}$ \\
7 & $2.8 \mathrm{~b}$ & $6.8 \mathrm{~b}$ & $7.9 \mathrm{c}$ & - \\
VU2 & & & & - \\
$0\left(\right.$ Control $\left.^{*}\right)$ & - & - & $16.9 \mathrm{a}$ & $14.6 \mathrm{a}$ \\
4 & 9.6 & 30.9 & $14.2 \mathrm{ab}$ & $12.9 \mathrm{a}$ \\
5 & 10.6 & 22.5 & $14.3 \mathrm{ab}$ & $13.2 \mathrm{a}$ \\
6 & 10.9 & 27.3 & $9.6 \mathrm{~b}$ & $6.3 \mathrm{~b}$ \\
7 & 5.9 & 20.8 & &
\end{tabular}

* Discarded after three months (overgrown)

Means with the same letter are not significantly different based on DMRT, $5 \%$.

\section{Tissue Viabilityand ex vitro Evaluation}

The capability of the plantlets maintained in mannitol-added medium to resume normal growth was tested after 13 months of incubation by transferring the whole plantlet or individual separated shoot into the normal growth medium. At 4\% mannitol, the plantlets resumed normal growth of roots and shoots (Table 2). Increasing the concentrations to 5$7 \%$ adversely affected tissue viability. Shoot growth was generally suppressed.

Based on the results, $4 \%$ mannitol seemed to be the best slow growth medium for in vitro conservation of yam. The plants can be maintained for more than one year without subculture and without affecting tissue viability. In addition, morphological variation of in vitrostored plantlets was not observed either during in vitro growth resumption in normal growth medium or under ex vitro condition. During ex vitro evalutation in pots, tuber yield of plants derived from slow growth (4\% mannitol) and normal growth cultures were comparable, about $277.5 \mathrm{~g}$ and $260 \mathrm{~g}$ for 'Kinampay' and $471.7 \mathrm{~g}$ and $442.5 \mathrm{~g}$ for 'VU2', respectively. 

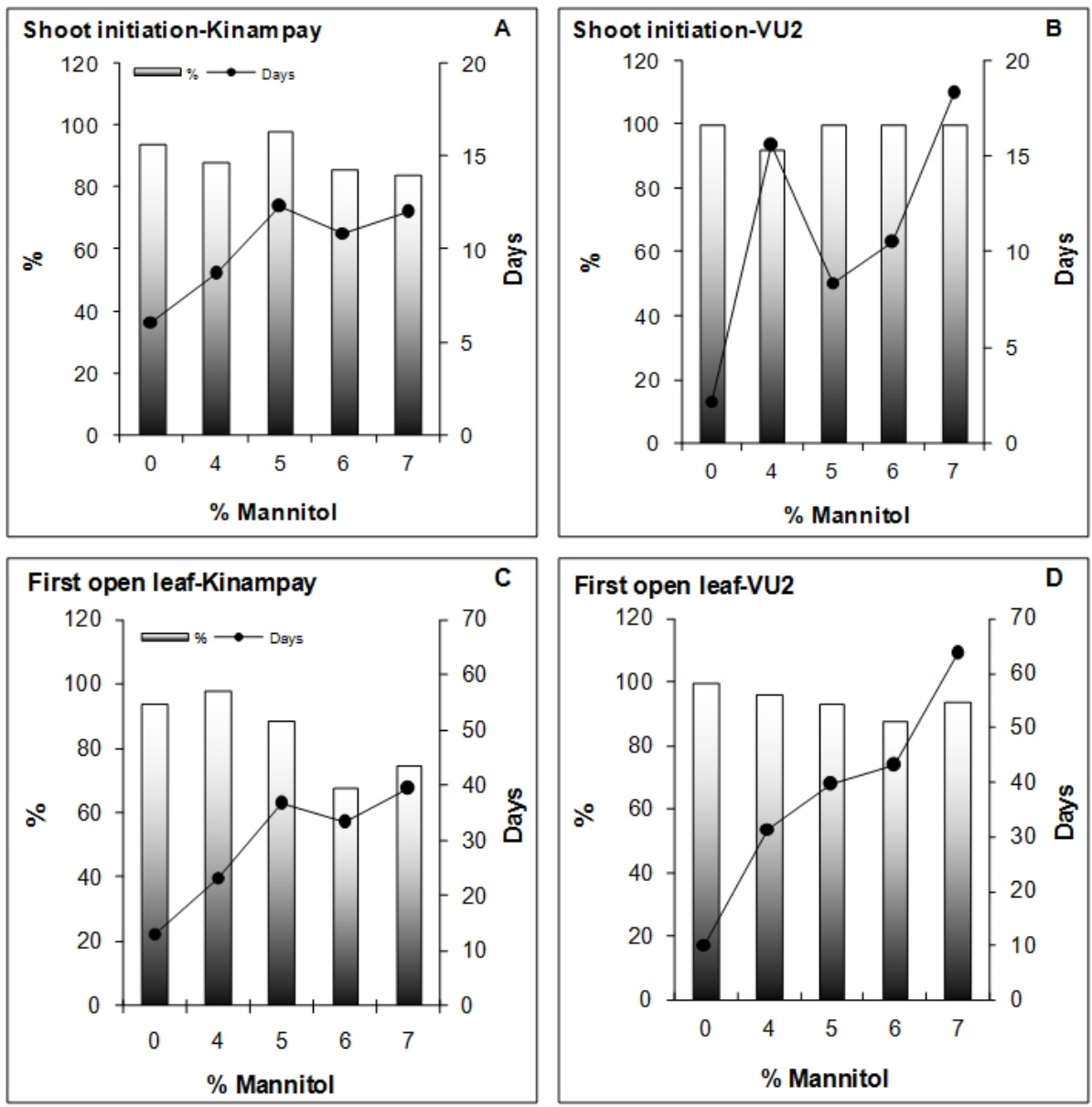

Figure 10. Shoot initiation and production of first open leaf in nodal cultures of 'Kinampay' and 'VU2' yam treated with 0-7\% mannitol. 

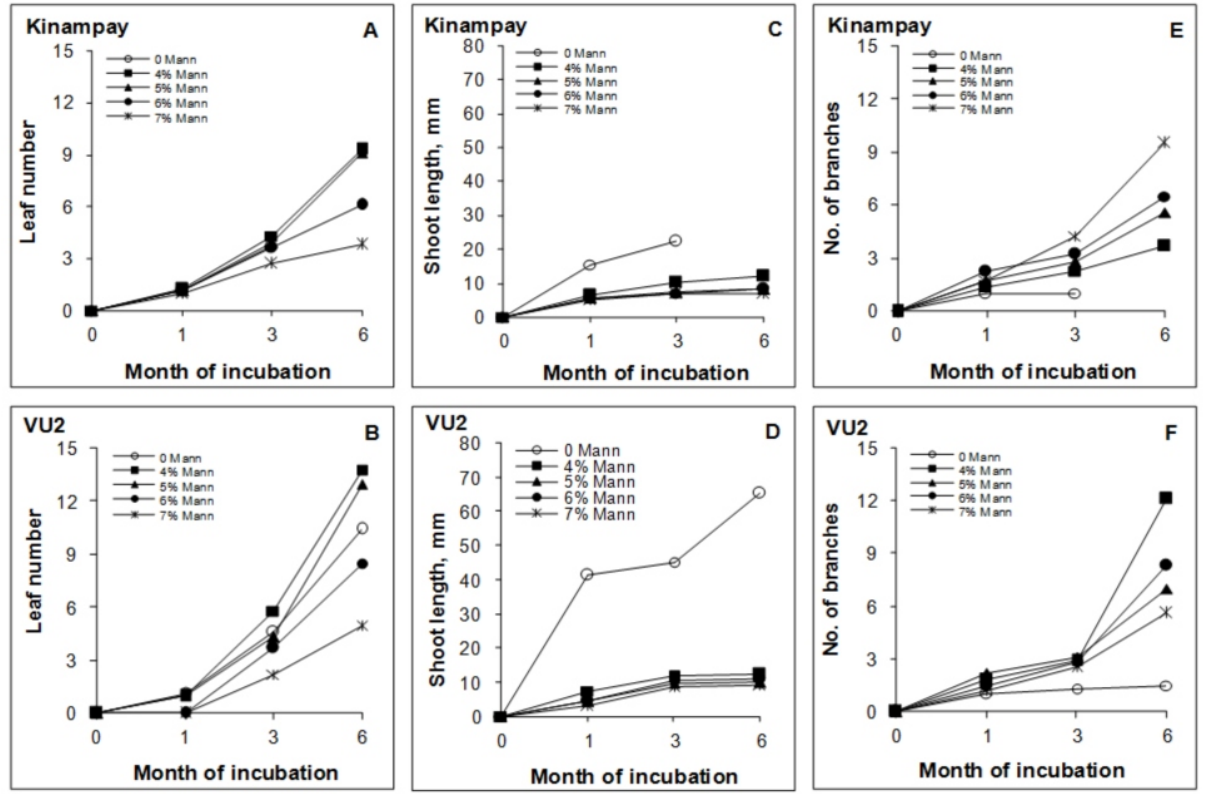

Figure 11. Number of leaves and branches and shoot length of nodal cultures of 'Kinampay' and 'VU2' yam treated with 0-7\% mannitol.

Kinampay
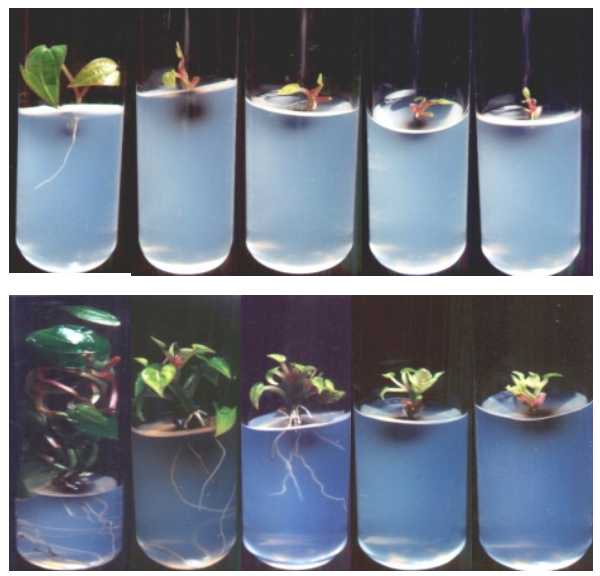

a

b

c

d

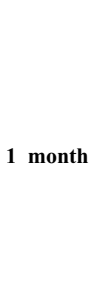

VU-2
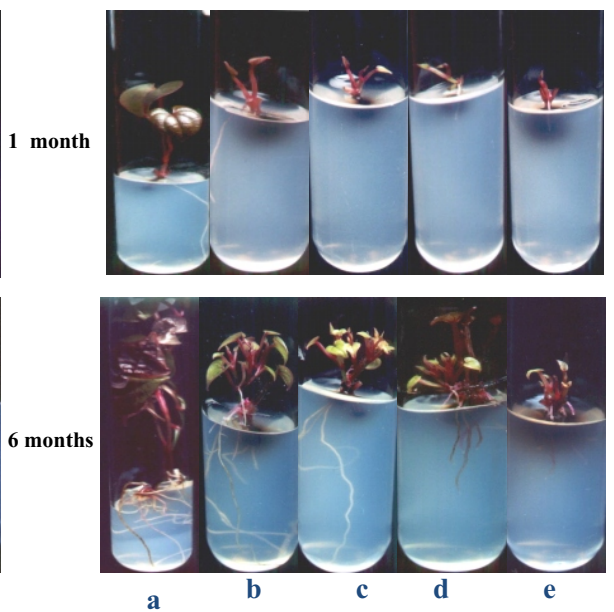

Figure 12. Growth of 'Kinampay' and 'VU2' yam nodal cultures after 1 and 6 months of incubation in mannitol-added medium: (a) control; (b) 4\%; (c) 5\%; (d)6\%; and (e) $7 \%$. 
Table 2. Viability testing using normal growth medium of 'Kinampay' and 'VU2' yam cultures stored in vitro for 13 months in mannitol-added medium.

\begin{tabular}{llcc}
\hline \% Percent Manitol & Explant & Shoot Growth & Root Growth \\
\hline Kinampay & Whole & + & + \\
4 & Sep. shoots & + & + \\
& Whole & + & - \\
5 & Sep. shoots & - & - \\
VU2 & Whole & + & + \\
4 & Sep. shoots & + & + \\
& Whole & + & - \\
5 & Sep. shoots & + & + \\
6 & Whole & + & - \\
7 & Sep. shoots & + & - \\
7 & Whole/Sep. shoots & - & - \\
\hline
\end{tabular}
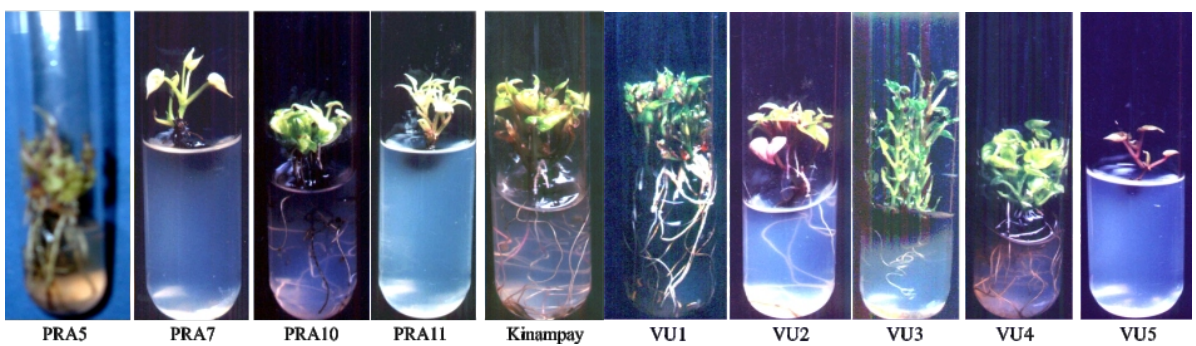

Figure 13. Growth of nodal cultures of different yam genotypes after 6 months of incubation in $4 \%$ mannitol-added medium.

Responses of Other Yam Genotypes

Mannitol at 4\% was used as the slow growth culture condition for the other yam genotypes, 'VU1', 'VU3', 'VU4', 'VU5', 'PRA5', 'PRA7', 'PRA10' and 'PRA11. Similar growth retardation was obtained as illustrated in Figure 13 which shows the growth appearance of the different genotypes after 6 months incubation.

\section{CONCLUSION}

Among the three growth retardants used, mannitol at $4 \%$ was the most promising for slow growth culture of yam since plantlets resumed normal growth after more than a year of maintenance without adverse effect on morphological traits and tuber yield. Other yam genotypes have the same response to $4 \%$ mannitol. 


\section{IMPLICATIONS AND RECOMMENDATION}

In vitro conservation of yam germplasm is highly possible with the use of slow growth medium containing $4 \%$ mannitol. The tissues can be stored for at least one year without subculture which means saving about 4 times the cost of maintenance using the normal growth medium. This in vitro genebank could at least complement field genebank or at most could be resorted to when field maintenance of germplasm collections becomes too costly, risky and too slow when the need for planting materials arises. To assure the genetic fidelity of in vitro-stored plants, genetic evaluation using molecular markers is recommended. Virus indexing is also recommended to ensure that the genetic materials maintained in vitro are disease-free.

\section{ACKNOWLEDGEMENT}

Research grant from the Department of Agriculture-Bureau of Agricultural Research (DA-BAR) is gratefully acknowledged.

\section{LITERATURE CITED}

ACEDO, V.Z. 2003. Propagation of purple yam (Dioscorea alata L.) through tissue culture. Journal of Root Crops 29(2):7-16.

MALAURIE, B., TROUSLOT, M.F., BERTHAUD, J., BOUSALEM, M., PINEL, A. and DUBERN, J. 1998. Medium-term and long-term in vitro conservation and safe international exchange of yam (Dioscorea spp.) germplasm. Electronic Journal of Biotechnology 1:1-19.

MURASHIGE, T. and F. SKOOG.1962. A revised medium for proper growth and bioassays with tobacco tissue culture. Physiologia Plantarum 15:473497.

OKEZIE, C.E.A. 2003. An efficient protocol for medium-term conservation of the aerial yam, Dioscorea bulbifera L. in vitro. Bio-Research 1:43-52

RODRIGUEZ, A., VAZQUEZ, J., GARCIA, M., FONSECA, M., BORGES, M., AGUILERA, N., MENESES, S. and INFANTE, Z. 2003. In vitro conservation of Dioscorea alata L. germplasm by slow growth. PGR Newsletter 133:17. 